\title{
THE IMPORTANCE OF PUBLIC ADMINISTRATION IN ADMINISTRATIVE AND LEGAL REGULATION
}

\author{
Kateryna Berezhna ${ }^{1}$ \\ Nataliia Yuzikova ${ }^{2}$ \\ Serhii Maistro $^{3}$ \\ Viktor Paliukh ${ }^{4}$ \\ Liudmyla Antonova ${ }^{5}$
}

\begin{abstract}
The article examines a place, influence and significance of the category of «public administration» in the context of studying of juridical disciplines of administrative and legal cycle. It determines a number of prerequisites for clarifying a legal nature, in particular, a subject of the legal regulation of administrative law and administrative procedure through the influence of the category «public administration». The first section includes the procedural changes in the framework of system update of regulatory and legal base, first of all legislative one, in relation to the
\end{abstract} functional introduction of new institutes of administrative and legal cycle (the institutes of «administrative justice», «administrative services») and implementation of the results of performed administrative reform. The second section of preconditions includes theoretical and category changes in relation to the update of conceptual framework that are a logical result of the fundamental scientific achievements of the leading research-methodological legal administrative schools. The author's definitions for «public administration» and «public management» are formulated as well as

\footnotetext{
${ }^{1}$ Doctor of Juridical Sciences, Associated Professor, Head of the European and International Law Department, Oles Honchar Dnipro National University, Ukraine.

${ }^{2}$ Doctor of Juridical Sciences, professor of Department of administrative and criminal law, Oles Honchar Dnipro National University, Ukraine.

${ }^{3}$ Head of the department of public administration for civil defence of the National university of civil defence of Ukraine, (Ukraine), Kharkiv, Doctor of Sciences (Public Administration), Professor, Ukrain

${ }^{4} \mathrm{PhD}$ Student, National University of Civil Protection of Ukraine, Kharkiv, Ukraine

${ }^{5}$ Professor of the Department of Accounting and Audit of the Petro Mohyla Black Sea National University , (Ukraine), Mykolaiv, Doctor of Sciences ( Public Administration), Professor, Ukraine
} 
their correlation under the principle «from the general to the special» where public administration is the general concept and public administration is the special one. It is established that the category «public interest» is a system and forming component and actually, the basic one in interpreting «public administration». On the one hand, it is considered as a quintessence for the continuous implementation of public international and constitutional rights, such as: the right to form a governance (electoral law), to public service, to social security, and on the other hand as the activities of public bodies in the area of observance of the principles of legality, the rule of law, publicity, inevitability of punishment. The range of problems under consideration is evaluated in the articles published in the professional periodicals of Ukraine, in the papers of international and AllUkrainian conferences as well as in academic programs of disciplines «administrative law», «administrativeprocedure».

Keywords: administrative regulation, administrative law, administrativeprocedure, public administration, public management.

\section{Introduction}

At first glance, the relevant amendments, that is the change and update of the framework of categories and concepts of disciplines of administrative cycle in terms of the categories «state management) and «public administration), caused by banal borrowings of the foreign terminology. However, it is not quite so and partially corresponds to reality. Now, theoretical and legal category of «public administration» is increasingly applied in academic and scientific disciplinary use of administrative-legal cycle that greatly modifies, typical for the second half of the twentieth century, the Soviet conceptual identification (association) of administrative legal disciplines with the category «governance».

Therefore, it is clear that there is the foreign lexical influence on the transformation of governance into public administration in the case of a change of the obsolete categories base of administrative-legal cycle and in terms of the theoretical use of terminological legal vocabulary based on the foundations and principles of the concept of «governance» or «public administration)). But, in our opinion, this influence should be considered as a 
groundless or secondary, in other words, as narrow one.

According to our opinion, one of the answers relatively establishment of the primary factor for substitution of the terms «governance» for «public administration)), advantages of the application of «public administration» in the theoretical dimension of the sciences of legal and administrative direction, can be obtained if there is a particular definition of «public administration» established through analyzing specific characteristic features of this procedural activity, which, according to our position, is the most optimal approach.

\section{Literature review}

The analysis of foreign literature regarding the category of «public administration» actually testifies about the similarity of scientific positions regarding the content, purpose and classification approaches.

Thus, Singh H. and Sachdeva P. indicate that the term «administration» derives from Latin «administere», which means the care of people or affairs management. In opinion of scholars, administration can be defined as «group activities which include cooperation and coordination with the purpose to achieve desired goals or tasks».

In general, the term «administration» includes at least four different meaning depending on the context of use:

the first, as a discipline: the name of a field of study or discipline that was lectured in colleges and universities;

the second, as places, type of work (profession), especially it touches the process of knowledge obtaining and training, in fact human resources training;

the third, as a process, namely the total number of measures taken to implement public policy or policy for the provision of public services or goods;

the fourth, in the synonymous meaning of the categories «executive» or «government» (Singh et al, 2012).

In the general sense, the term «public administration» refers, above all, to the general management of society as a whole. Therefore, in the general sense, administration's activity is directed at shared benefit of the public through the implementation of public administration.

Other scholars, in particular Morenikeji A. and Oluwafemi J., consider public administration as the government activity on the formulation and adherence to state policy at the 
federal, state and local levels, as well as the implementation of executive and operational functions. At the same time, they emphasize the fact that public administration forms government activity for people. Due to the efficient and effective public administration, the government provides high-quality administrative services for a citizen (Morenikeji et al, 2014).

Marume S. B. M. says that public administration should be interpreted through the prism of two main approaches to the meaning of corresponding categories, in particular integrated one which is a comprehensive and covers all actions of the government and managerial approach, which will be more narrow in relation to the integrated and will provide management influence. According to this point of view, public administration covers all measures taken to achieve the goal of state power. In other words, public administration is the complex of managerial, technical, office and personnel activities (Ternushchak, 2016).

In fact, Uchem R. O. and Erunke C. E support almost the same position regarding the separation of public administration interpretation in the integral and managerial approaches, but the scholars consider this category from the position of integral and managerial schools. In particular, they emphasize that public administration is a relatively broad and comprehensive area that does not point to the specific direction and scope of public administration. Public administration, at the moment, crosses the line of governmental activities and ruling circles including other spheres, namely church, market, postal services, transport and international relations, etc. However, for a more detailed understanding of the scope of public administration it is advisable to use the following scientific schools: integral and managerial.

\section{Results}

The Integral School interprets public administration is a sum total of all the activities undertaken in fulfillment of public policy. These activities include not only managerial and technical functions but also clerical. The central argument of the integral scholars is that public administration is only concerned with all the activities of government undertaken by one or the entire three branch of government (Bublyk et al, 2017).

In its turn, the Managerial 
School sees public administration as an area that is specifically concerned with only those persons engaged in the performance of managerial functions in an organization. This implies that only those who plan, programme and manage the activities of an organization are the main focus of public administration. The functions of these people are numerous, and are geared towards the achievement of certain goals. For the first time, these functions were outlined in 1980 using the acronym POSDCORB, meaning: $P$. Planning, O. Organizing, S. Staffing, D. Directing, C.O. Coordinating, R. Reporting B. Budgeting (Uchem et al, 2013).

It also necessary to mention scientific achievements of Pommer E., Edwards G., Raadschelders Jos C. among the number of topical foreign and modern papers devoted to public administration (Pommer, 2016).

In general, we think that public administering is the activities of bodies of public administration towards satisfaction of public needs (interest) of natural and legal persons (Ternushchak, 2016), and public administration is a complex of state and municipal bodies the activities of which should be aimed at meeting public interest.
746

Therefore, in the context of relevant definitions and disclosure of the stated problem, we propose to pay a special attention to the term «public interest», which will act as a systemgenerating, primary characteristic of the category «public administration) in a particular situation (Koval, Pukala, 2017). In our opinion, such a characteristic feature as publicity equally acts as a qualifying one both for «public administration» and «governance» in terms of the legal nature of administrative legal relationship where an entity of authoritative power always acts as one of the parties (subjects) regardless of a situation and subject (Koval et al, 2019).

We support and share the position of R. Melnyk and S. S. Mosondz on the definition of «public interest» as a conscious interest of the whole society, which is a reflection of the economic, social and law-enforcement needs of the population (Melnyk, 2015), and we propose to indicate that public interest in public administration, on the one hand, is the quintessence for an unhampered implementation of public international and constitutional rights such as follows: the right to form power (electoral law), to public service, to social security, and 
on the other hand is the activities of public bodies in observance of the principles of law, rule of law, transparency, inevitability of punishment, and others.

Consequently, the term «public interest) in the context of the category of «public administration» will obtain basic, as noted, system-forming content and will be a theoretical reflection of the ideal model of state functioning in terms of partner activities of public authorities and citizens, the relationships formed on trust and compliance with laws (Leheza et al, 2018).

Moreover, public interest, in accordance with the modern theory of «anthropocentrism» in administrative study, is the purpose of the activity of public authority by its bodies. However, depending on a political, economic and social environment, the realization of public interest may not coincide with the democratic principles and foundations in full, above all it touches the application of public coercion, but within the statutory limits, in the case of emergency or other essential conditions (for example, in the context of anti-terrorist operation).

In support of this statement, in 1911, A. Yelistratov wrote that public interest would always be the subjectmatter of the relations between a representative of state power and citizens. In this context, an outstanding scholar noted that the public interest takes government for common interest, this, in turn, depends on the level of population's culture. And what government considers as a public weal, in fact, can differ from the interests of a large part of the population. But, in any case, the demands of the ruling government are placed on citizens not as a private interest of individual representatives of power, but for the public good (Elystratov, 1911).

In turn, the category «state administration), which according to the Soviet legal tradition and heritage, closely correlates with state control over the activities of public bodies like administrative-team cooperation but in essence it is a strict control of one entity over the activities of other in the aspect of functioning of public power, is not relevant taking into account the ephemeral effectiveness of administrative-team system of public administration in comparison with the present not the best state of affairs.

In our opinion, advantages of the concept of «public administration» 
over the concept of «governance» in relation to the formation of terminology framework of administrative-legal cycle in the modern circumstances is obvious, and fist of all it caused by the politicalsocial European integration process, a course chosen by political officials and expected public desire for shifts and changes in fortunes.

Analysis of theoretical scientific basis which usually has solutions of the problem is no less important aspect in revealing the essence of any issue as well as in developing any subject-matter. Thus, other answer to the expediency of change of administrative terminological categories of «governance» into «public administration» we will get after the analysis of different opinions, subjective points, and ideas of leading scholars in administrative study.

In a textbook «Administrative

Law» T. Hurzhii stresses that «administering» is activities of administration on adjustment of subjects' actions (bodies, units, enterprises, institutions, organizations) and, in addition, he divides this term into such subtypes (according to the criterion of interest implementation):

public administering (implemented for the purpose of realizing public interests);

- private administering (implemented for the purpose of realizing private interests);

- corporate administering (implemented for the purpose of realizing corporate interests) (Hurzhii, 2013).

In our opinion, the author's (T. Hurzhii) approach to the definition of «administering» is more in line with the category of «management», as activities on actions adjustment of subordinate subjects will mean a certain imperative component specific to administrativeteam principle, but not a dispositive component specific to partner relationship. Nobody denies that any activity, either in public bodies or at a private enterprise, based on subordination, for example following the conditional construction «authoritiesapparatus-staff». At the same time, coercion application is not always a key for discipline and successive team cooperation, more often moral and finance encouragements and others serve as more effective mechanism. Moreover, in practice, the terms as «dependent» and «subordinate» are interpreted by employees in an ambivalent manner, and 
don't promote harmony keeping in team.

In turn, we completely share the position regarding the division of «administering» into public, private and corporate according to the criterion of interest implementation.

R. Melnyk in a textbook «General administrative law» concludes that «public management» is an activity connected with the internal organization of functioning (reorganization of divisions, transfer of civil servants, implementation of disciplinary liability) of public authorities, and «public administration» is a general concept which cover subjects the main task of which is enforcement of the Constitution and laws (Melnyk, 2015).

We support the abovementioned definitions of «public management» and «public administration», and taking into account the definition of public management as an internal organization of activity of public subjects we see it expedient to correlate, partially, similar terms «public administration» and «public management» according to the principle «from the general to the special). In this term, «public administration» acts as the general, and «public management» acts as the special (Tamosiuniene et al, 2019).
In our opinion, public administration is a general activity of public authority on satisfaction of public interest (it was mentioned above) regardless of a typology of administrative relations that consists a general subject of administrative law. And the approach of R. Melnyk specifies public management as internal organizational activity of public authority that, in our opinion, provides practical realization of public relations subject of which may be:

the first, processes connected with the beginning, service career and discharge from public service;

the second, implementation of tasks and functions, which are established by staff arrangement of official powers, as well as tasks, duties, instructions of direct and senior leaders of a body where a person works.

There is a quite similar approach of Frederick C. Mosher, who in his own article on «Britannica» encyclopedia resource, says that in our time «public administration» should be compared with the responsibility for determining of policies and development government programs, namely, for planning activities, organization, management, coordination and control 
over national and government operations.

A non-standard but surprisingly relevant analysis of the category «public administration» which has been conducted by T. Kolomoiets, a wellknown Ukrainian academic lawyer, sparks interest and draws attention. Thus, a textbook «Administrative law of Ukraine. Academic programme» considers the term «public administration» in the context of double meaning of its certain components. The first is «publicity» that is a set of features of procedural activity of administrative entities, such as: a common, accessible to all, serving all, combines state (national) and self- governing (territorial). The second is «administration» namely, indications of subordination to political power and service to the public interest (Kolomoiets, 2011).

We believe that performed individual analysis of the components of public administration, and in fact the explanation of the terms of «publicity» and «administration» which was presented in terms of distinguishing typical, characteristic features of the terms, the key place among which, according to our belief, is hold by community, accessibility, service to the public interest, comprehensively emphasizes the purpose of public administration.

Domestic scholars D. Pryimachenko and R. Ihonin reffering to I. Vasylenko, Russian scholar, consider public administration as coordinated group actions in state affairs:

firstly, which are connected with the three branches of power legislative, executive, judicial and their interaction;

secondly, which are important for the formation of state policy and which are a part of the political process; thirdly, which significantly differ from administration in the private sector; fourthly, which are closely linked with numerous private groups and individuals working in different companies and communities (Kolomoiets, 2014).

The corresponding position, in our opinion, is not quite clear and doesn't correlate to the majority of features of public administration.

If we can partially agree with the statement that coordinated activity in state affairs indirectly characterizes public administration, however the terms «coordination» and «state affairs» should be referred to a speciality of 
public management and sphere of social (political) sciences, so the first three features should not be linked to public administration. In the first and second cases, the interconnection of branches of power and the formation of a state policy in the context of satisfaction of political interest is a subject-matter of state (constitutional) law. In the other two, in particular, the third feature indicates the difference in administration in the private and public sectors, which is obvious, but there is no specification for the essence of the relevant differences.

In respect to the provision of the fourth feature of «public administration» (from the point of view of I. Vasylenko, D. Pryimachenko, R. Ihonin) it touches the fact that coordinated actions within state affairs are closely connected to private actors who work in different companies and communities, we see it actual and such that corresponds to the essence not only the category «public administration» but also to the categories «state management) and «public management).

Covered the core of the terminology structure of «public administration» in administrative science, it is necessary to clarify the category of «administrative-legal cycle», that is, the legal disciplines which, in full or indirect forms, reflect the content, features and essence of public administration in Ukraine in the prospect of a profound analysis of the characteristics of a relevant category and in the context of legal administrative disciplines,.

Thus, primarily, legal disciplines of administrative-legal cycle, which are taught in higher schools (institutions of 1-4 levels of accreditation), as well as of exclusively legal or specialized-legal aspect and broad-profile ones, should involve such classical disciplines as «administrative law» and «administrative procedure). However, taking into account the broadspectrum updating of the legislative and sublegislative administrative framework, and in fact the categories transformation of the legal basis of the state and municipal sector activities, which is conditioned by a number of social upheavals in terms of change and turn of the political vector of the state development as a whole, there is also a practical need for a clear adjustment, systematization and amendments of educational discipline base, in our case it concerns the disciplines of administrative-legal cycle. 
The current legislation, in a specific way, prompts and contributes to academic and research institutes and their structural units (institutions, faculties, departments) that they develop more new courses, including special courses of study, on administrative subject matter. This is especially topical when, as already mentioned, certain essential regulatory changes take place, which, in turn, act as a theoretical precondition that pushes domestic administrative scholars to develop and introduce a new categories base, as well as future newest institutions. Or on the contrary, scientific developments in administrative science can serve as a promotional mechanism for the domestic legislator on regulatory framework development.

For example, the pioneered institute of «administrative services) that was introduced to administrative law and obtained a final statutory-perfect form in 2012 (after approval of the Law of Ukraine «On Administrative Services)), and a certain structural-forming regulatory and theoretical outlines from the middle of the XXI century (2006) (Pysarenko, 2006).

Currently, the instituion of administrative services, without exaggeration, is one of the key priorities of improving the activities of executive and municipal authorities. Specifically, the European model of public administration, which we have previously described as public administration in the context of the fact that the current political leadership of the state is gradually implementing the relevant practice in various spheres of public activity of the executive government and local self-government, is successful in nature, convenient for the public and business. In particular, this is a systematic formation of new centers for the provision of administrative services, the introduction of new IT-services on the electronic web- resources (websites, portals), and improvement of the procedure services provision through the elaboration of new electronic operating systems of document circulation based on the principle of «single window system» and others.

In its turn, regulatory and theoretical-categories changes (Ternushchak, 2016) touched the institute of «civil and municipal service» which automatically evolved into the institute of «public service» after the availability a rule (para. 15 p. 1 Art. 3) in the Code of Administrative Procedure of 
Ukraine (hereinafter referred to as «the CAPU») according to which public service is activity performed in public political posts, professional activities of judges, public prosecutors, military service, alternative (non-military service), diplomatic service, other civil service, service in power structures of Autonomous Republic of Crimea, local self-government bodies.

Well, in essence, the main innovation of administrative-procedural science in the part of separation of the new institute of administrative law administrative justice (legal proceedings) that was transformed at the scientific and theoretical level into a separate discipline «administrative legal proceeding», was the fact that in 2004 the Code of Administrative Procedure was adopted and came into force in 2005.

Moreover, depending on the methodological achievements of structural units of higher education institutions and scientific developments of some law schools, the legal relations of administrative justice are objects either of individual disciplines such as «administrative legal proceeding», «administrative procedure» or of a fundamental discipline of administrative-legal cycle «administrative law».

Currently, an active phase of the reform processes concerning the activities of public administration continues in Ukraine. In particular, the adoption of the Law «On Administrative Services» in 2012 was a significant event of legislative and statutory consolidation of the norms that would be applied to minimize the barrier of bureaucratic and corrupt character to receive services from the subjects of authoritative powers. It should be noted that the adoption of this Law has also substantially affected the change of the generally established theoretical positions of certain legal branches.

Therefore, the consequences of these legislative, scientific and academic modifications in the development of new institutes of administrative-legal cycle lead to the introduction on the new disciplines of administrative-legal and procedural focus, which were not taught separately, were introduced to domestic higher education institutions, in particular to their structural units. At the modern stage (the end of the first decade of the XXI century) such disciplines include courses as follows: «administrative reform», «legal regulation of administrative services 
provision» and others;

before (in most cases from the beginning of 2005): «administrative legal proceedings), «administrative justice), «actual problems of administrative legal proceedings» and others;

in earlier times (the end of the XX - the beginning of XXI century): «administrative-tort law», «administrative responsibility) and others.

However, in our opinion, the influence of the category of public administration in relation to the disciplines of administrative-legal cycle is reflected to the outmost in the discipline «Legal regulation of public (state) management» the subject-matter of which is provisions of Ukrainian regulatory framework, academic theoretical provisions on administrative law and procedure, which present actual problems of realization of administrative and legal norms, the modern development of branches reform of administrative and legal cycle connected with the change of categories and concepts framework and refresh of administrative legislation. The issues and problems directly touching public administration are studied within a particular discipline, in particular the specific nature of beginning, career and termination of public service; peculiarities of provision of administrative services by executive and local self-government bodies; administrative reform in certain spheres of public management.

It's no good to skip the issue of administrative reform as now Ukraine begins to reform almost all spheres of public administration as well as to initiate reforming of justice system and related legal institutions. We note that a successful implementation of some reforms directly and indirectly depends on a complex approach to introduction of measures of legal and organizational nature, multiagency coordination of the branches of government, impartial public control and totally apolitical nature of the nation's leadership.

In general, administrative reform is a process of adoption of a relevant regulatory framework that will contribute to the formation of an institutional structure of public management which will completely meet public interest, in other words the priority of their activities will be devotion to people and the national interests of the country. In more narrow 
interpretation, administrative reform is a complex of measures aimed at updating administrative and legal status of reform's actor (administrative or other body) by virtue of optimization of servants' number, improvement of institutional coordination of teamwork of structural subdivisions at the central and regional levels, improvement of electronic, information and financial security of employees, simplification of the procedures for provision of administrative services etc.

At the moment, attention is drawn to the range of branching of areas and spheres of public administration where administrative reform is taking place. In particular, this is a reform of the activity arrangement of public administration bodies components of which include: administrative-territorial (decentralization).

In essence, the implementation of the relevant reform will be in the unification of the territorial communities of villages, settlements, and cities in accordance with the principles of polycentric nature, subsidiarity and the procedure prescribed in the provisions of the Law «On Voluntary Association of Territorial Communities). A gradual unifying of territorial communities will not only contribute to optimization of the territorial organization of local authorities in relation to change of insufficiently capable administrative units by self-reliant ones, which will be able to ensure the expected, proper level of public administration in the field perfectly but also to increase financial income in local budgets. Moreover, the next stage of decentralization should be the process of reorganization of local state administrations and the introduction of prefecture institute with control powers over the observance of the Constitution and laws of Ukraine by local self-government bodies, and the coordination of the activities of territorial bodies of central executive authorities.

- provision of administrative services reform.

The reform is related to the procedural improvement of the provision of administrative services, which was launched in 2012 since the adoption of the Law «On Administrative Services), is actively implemented and practiced in almost all territorial executive authorities and local self-government bodies. Usually, the centers of administrative services, activities of which are divided according to the 
principles of «front and back office) and «single window) function as separate units or official places in the abovementioned bodies.

reform of the improvement of administrative and legal support, such as legal, personnel, financial, information, logistical, for the activities of administrative bodies.

In turn, from the beginning of 2013, other public reforms have been implemented in Ukraine, in particular, the reform of judicial system and related legal institutes (advocacy, public prosecution, and penalties system); reform of the system of prevention and counteraction of corruption (anticorruption); reform of the law enforcement system.

In addition, up to date, taking into account the focuses of administrative reform that have been conducted and are being implemented, the main stage of administrative reform should include:

1. Reform of the institute of administrative justice (2004, Adoption of the CAPU).

2. Establishment of a new institute of administrative law - the institute of administrative services (2011, adoption of the Law «On Administrative Services)).
4. Reform of the institute of public service (2016, adoption of a new Law «On Civil Service).

5. Reform of the judicial system and related legal institutes (2016, amendment of the Constitution of Ukraine (in relation to justice system).

6. Administrative-territorial reform (decentralization in the part of voluntary association of territorial communities (2015, the Law «On Voluntary Association of Territorial Communities»).

\section{Conclusion}

From the middle of the XXI century, the category of «public administration» is actively used by administrative scholars (Kolomoiets T., Kolpakov V., Kuzmenko O., Melnyk R., Pryimachenko D.) in connection with the reinterpretation of the doctrinal concepts of the development of administrativelaw school (from the theory of «management» to «anthropocentrism»), borrowing of foreign academic and research methodology, in terms of «administrative law» studying, the implementation of best practices of the regulatory provisions of the European and American laws in the domestic legislation and a number of other 
political and socio-economic factors related to European integration processes.

Now, the need to implement a theoretical category «state management) in the context, above all, of administrative law almost disappears and has lost its sense due to longstanding transformation of categories and concepts framework in relation to the substitution of the category by «administrative administration» and «public management).

Public administration is the activities of public administration bodies in meeting public needs (interests) of individuals and legal entities in various spheres of public administration (Yankovyi et al, (2020).

The system-forming component, in fact basic one in interpreting «public administration», will be «public interest», which on the one hand will be considered as the quintessence for the continuous implementation of public international and constitutional rights, such as: the right to form a governance (electoral law), to public service, to social security, and on the other hand as the activities of public bodies in the area of observance of the principles of legality, the rule of law, publicity, inevitability of punishment.

Public administration is, in general, an internal organizational activity of public entities, and in detail it is processes connected with entry, career and termination of public service; performance of the tasks and functions determined by staff arrangement of the official powers of the body where a person works, as well as tasks, orders, instructions of direct and senior leaders; organizational and legal support of functioning of a public body (statutory, personnel, financial, logistic).

The correlation of the categories «public administration» in relation to «public management» meets the principle «from the general to the special» where public administration is the general concept and public administration is the special one.

An obvious influence of the concept «public administration» on the development of legal disciplines of administrative and legal cycle is due to: - $\quad$ normative changes in the context of the system updating of the regulatory framework, especially of the legislative framework, when it touches the functional introduction of new institutes of administrative legal cycle (institutes 
of «administrative justice (the CAPU, 2005)», «administrative services (Law of Ukraine «On Administrative Services,)); - theoretical and categories changes in the part of the concepts updating and the thematic content of the disciplines of administrative-legal cycle, in particular, of the legal regulation of state administration, act as the logical accomplishment (result) of the fundamental scientific developments by the leading reseacrh and methodological legal administrative schools.

\section{References}

Bublyk, M., Koval, V., \& Redkva, O. (2017). Analysis impact of the structural competition preconditions for ensuring economic security of the machine building complex.Marketing and Management of Innovations, (4), 229240.

Edwards, G. (2019). Introduction to public administration. Retrieved from: https://ebooks.wtbooks.com/static/wtbo oks/ebooks/9781978926196/978197892 6196.pdf.

Elistratov, A.I. (1911). Administrative law. Moscow.Type. I. D. Sytin,

Hurzhii, T.O. (2013). Administrative law of Ukraine: textbook. manual. Kiev. KHT. Burun and K.
Kolomoiets, T.O. (2011). Administrative law of Ukraine. Academic course: textbook. Kiev. Jurinkom Inter.

Kolomoiets, T.O. (2014). Administrative law of Ukraine: dictionary of terms. Kiev. In Jure.

Koval, V., \& Pukala, R. (2017). Implementation of regulatory policy in economic activity: development of the institute regulatory impact assessment. Economics. Ecology. Socium, 1), 24-32.

Koval, V., Nazarova, K., Hordopolov, V., Kopotiienko, T., Miniailo, V., \& Diachenko, Y. (2019). Audit in the state economic security system. Management Theory and Studies for Rural Business and Infrastructure Development, 41(3), 419-430.

Legislation of Ukraine. (2006). On approval of the Concept of development of the system of providing administrative services by executive authorities: Order of the Cabinet of Ministers of Ukraine of February 15, 2006 № 90-r (with changes and additions). Cabinet of Ministers of Ukraine.

http://zakon4.rada.gov.ua/laws/show/90 -2006-p.

Leheza, Ye., Savielieva, M., Dzhafarova, O. (2018). Structural and legal analysis of scientific activity 
regulation in developed countries. Baltic Journal of Economic Studies. 4 (3), 147157. https://doi.org/10.30525/22560742/2018-4-3-147-157

Melnyk, R.S. Mosonds, S.O. (2015). Administrative law of Ukraine (in schemes and comments). textbook. manual. Kiev. Jurinkom Inter.

Melnyk, R.S. Pukhtetska, A.A.. Gritsenka, I.S. (2015). General administrative law: a textbook. Kiev. Jurinkom Inter.

Morenikeji, A. Oluwafemi, J. Towards, A. (2014). Theoretical Definition of Public Administration. Journal of Business and Management. № 3(16). 65-70.

Pisarenko, G.M. (2006). Administrative services in Ukraine: organizational and legal aspects: author's ref. dis. Cand. jurid. $\quad$ Sciences: $\quad 12.00 .07$ «Administrative law and process; finance law; information law ". Odessa. Pommer, E. (2016). Public administration in Europe. Zarzadzanie Publiczne. № 2(36). 34-52.

Public Administration: Definition, Nature and Dimension (article). Retrieved from: http://www.yourarticlelibrary.com/publi c-administration/public-administrationdefinition-nature-and-dimension/63417.
Raadschelders Jos, C.N. (2015). Government: A Public Administration Perspective. 2nd ed. Retrieved from: https://books.google.com.ua/books?id=z ffqBgAAQBAJ\&pg= PA46\&lpg=PA46\&dq=public + administ ration + definition $\&$ source $=$ bl\&ots $=\mathrm{DBm}$ q501sHb\&sig=Pb5sMZ1IWP3xZgtteuI2j6fi84\&hl=uk\& $\mathrm{sa}=\mathrm{X} \& \mathrm{ved}=$ 0ahUKEwi7mrrNxtjbAhUpM5oKHcBT As04ZBDoAQguMAE\#v=onepage $\& \mathrm{q}=$ public\%20administration $\% 20 \& \mathrm{f}=$ false. Singh, H. Sachdeva, P. (2012). Public Administration: Theory and Practice. Dorling Kindersley. Retrieved from: http://egyankosh.ac.in/bitstream/123456 789/ 25454/1/Unit-1.pdf.

Tamosiuniene, R., Demianchuk, M., \& Koval, V. (2019). State regulation of bankruptcy relations in the national economy. Economics. Ecology. Socium, 3(4), 19-27.

Ternushchak, M.M. (2016). Course of lectures on administrative law (general part): thesis formulations. Uzhhorod. Citizenship.

Ternushchak, M.M. (2016). Legislative changes in the interpretation of the term "civil service": a comparative analysis of the laws on civil service in 1993 and 2015. Current issues of the new Law of 
Ukraine "On Civil Service": All-

Ukrainian Forum of Administrative

Scientists. Zaporizhzhya. ZNU.

Uchem, R.O. Erunke, C.E. (2013).

Nature and scope of public administration. International Journal of Development and Sustainability. № 1. 177-182.

Yankovyi, O., Koval, V., Trokhymets, O., Karpenko, M., \& Matskevich, Y. (2020). Economic assessment of investment on the basis of production functions. Revista TURISMO: Estudos e Práticas, $(2$ 